\title{
Answering the Challenge of Era 4.0 in Vocational Education with Developing Multimedia
}

\author{
$1^{\text {st }}$ Fivtyka Odiana, $2^{\text {nd }}$ Roemintoyo, $3^{\text {rd }}$ Budi Siswanto \\ \{ fivtykao@gmail.com ${ }^{1}$, roemintoyo@yahoo.co.id ${ }^{2}$, budisys@yahoo.co.id ${ }^{3}$ \} \\ Sebelas Maret University, Indonesia ${ }^{1,2,3}$
}

\begin{abstract}
Media development is intended to answer the challenges that will be faced in the 4.0 era. Changes in the world are now entering the industrial revolution era 4.0 or the fourth world industrial revolution where information technology has become the basis for human life. Vocational education has certain characteristics as education which is different from other types of education. Therefore, it is expected that vocational education must be better prepared to face the 4.0 era. Preparation of a more innovative learning system in vocational education was carried out to encourage economic growth and national competitiveness in the era of the Industrial Revolution 4.0. One such preparation is with multimedia development.
\end{abstract}

Keywords: development, vocational, multimedia

\section{Introduction}

Industry 4.0 was launched in 2015 by German Chancellor Angela Merkel at the World Economic Forum (WEF). Klaus Schwab as the founder of WEF was so eager to publish the industrial era 4.0 that was followed by other world thinkers. Prof. Schwab (2017) describes the industrial revolution 4.0 in his book entitled "The Fourth Industrial Revolution", that the industrial revolution 4.0 has fundamentally changed human life and work. Unlike the previous industrial revolution, this 4 th generation industrial revolution has a wider scale, scope and complexity.

The industrial revolution 4.0 opened many opportunities for anyone to grow up. Information technology that is increasingly accessible to all corners causes everyone to be connected on a social network. Many conveniences and innovations are obtained with the support of digital technology. Services are faster and more efficient and have a wider range of connections with online systems.

The fourth generation industrial revolution not only provides opportunities, but also challenges the milineal generation. The progress of science and technology as a trigger for the industrial revolution was also followed by other implications such as unemployment, human vs. machine competition, and increasingly high competency demands. Therefore, to take advantage of opportunities and answer the challenges of the 4.0 industrial revolution, students must have data, technology and human literacy skills.

Education is an activity that is carried out in a planned. In line with the development of science and technology in Indonesia, various efforts to improve the quality of education 
continue to be carried out. One of them is the development of learning media. Responding to the challenges of the industry 4.0 The Commission on Adult Vocational Teaching and Learning (2013) identified eight distinctive features of vocational pedagogy; 1) developing occupational expertise through sustained practice and understanding theory; 2) having workrelated attitudes (central to developing occupational expertise); 3) using practical problemsolving and critical reflection on experience; 4) developing collaborative and contextualised teaching, involvingdifferent types of 'teacher'; 5) keeping on top of technological developments; 6) using assessment and feedback methods involving teachers and learners; 7) benefitting from operating across more than one setting including a real or simulated workplace; 8) having dynamic occupational standards which evolve to reflect advances in work practices. [11]

Vocational education and training is an educational approach that emphasizes the needs of the industry so that individual improvement and development can be done in the industry [14]. Based on existing theories, vocational education has the opportunity to answer the challenges of industry 4.0. These challenges must be answered quickly and accurately by actors in vocational education. This time to answer the challenge, researchers developed a media as teaching material in the Concrete Structure course in the Building Engineering Education study program.

The concrete structure is a subject with an emphasis on understanding the behavior of concrete in general when given a certain burden. Concrete structure for students of Education Building techniques become a subject that is so important related to their responsibilities after graduation. After graduation, students will teach vocational high schools in construction engineering and property businesses or work in construction services companies that require the ability to calculate concrete structures.

Media is one means to provide stimulation to learning and is deliberately designed to be used by students. The media and tools used can be media that is already available in schools or media developed by the instructor according to the needs and demands of the development of learning technology. Therefore, teachers as professionals are expected to be able to continue to develop new innovations in learning.

\section{Methods}

In this study, using research and development methods. The product to be developed is an interactive multimedia course Concrete Structure square beam reinforcement material.

\subsection{Procedure}

Procedural models developed using a model developed by Borg \& Gall (1989). The procedure for developing this research was modified in accordance with the needs of the developer, namely by adding in-depth interviews to the lecturer lecturers. In accordance with the opinion of Nesbit, Li \& Leacock (2006) The design of multimedia learning materials is frequently informed by relevant research in psychology and education. The flow of media development procedures is as follows; 1) Research and Data Collection; 2) Initial Model Planning; 3) Product Development; 4) Expert Validation; 5) Product Repair; 6) Field Trials and Lecturer Interviews; 7) Completion of Final Products 


\subsection{Research Subject}

This research was conducted from March 2018 to July 2018. This study used purposive sampling, conducted on students in the fourth semester of the 2017/2018 academic year with 30 students in the field trial.

\subsection{Data Collection Techniques}

Data collection techniques used are observation, interviews, and questionnaires. Observation techniques are carried out based on direct or indirect observations made by researchers which make it possible to see, observe, and record the behavior and activities that occur. Interviews are conducted by researchers on subject lecturers. The purpose of this interview is to get information about students' understanding of Concrete Structure, the opinion of lecturers on the media developed by researchers and learning activities that take place in the classroom. Questionnaire is given to validators, namely material experts, media experts, and students as users. The content of the questionnaire is in accordance with the capacity of each validator.

\subsection{Data Analysis Techniques}

Data analysis is used to process data obtained after conducting research, so that a conclusion can be obtained about the object of the study in actual circumstances. The level of feasibility of learning media is assessed by media experts, material experts, and students as users.

Table 1. Assessment Criteria

\begin{tabular}{clll}
\hline Score & Interval & Category & Conversion \\
\hline 4 & $3.25 \leq \overline{\boldsymbol{x}} \leq 4.00$ & Good & Eligible \\
3 & $2.5 \leq \overline{\boldsymbol{x}}<3.25$ & Pretty good & \\
2 & $1.75 \leq \overline{\boldsymbol{x}}<2.5$ & Less & Not Eligible \\
1 & $1 \leq \overline{\boldsymbol{x}}<1.75$ & Very Less & \\
\hline
\end{tabular}

If the analysis of the validator response data produced shows the conversion of the "feasible" category or get a score with a range of $2.5<\bar{x} \leq 4$ then the learning multimedia can be used and feasible to use. If the result of the validator response data shows that the conversion of the category "not feasible" or get a score with a range of values $1 \leq \bar{x} \leq 2.5$ then the learning multimedia is not feasible to use and needs to be revised.

\section{Results}

\subsection{Preliminary Study Phase}

In the field study phase, an analysis of the obstacles experienced by students during the learning process of Concrete Structures was carried out. Observation activities occur when the researcher becomes an assistant in the Concrete Structures course when doing corrections on 
the assignments to the 5th semester students. From the observations obtained, observation data shows that students did more errors when working on calculations in the beam chapter which results in them having to repeat calculations from the beginning. They did not understand the picture and still imagine, there is no picture of reinforcement if applied in the field. In addition, the researcher also analyzed the results of the assessment in the form of evaluation values and student assignments obtained from the lecturers. Whereas in the assessment the value of students has not achieved maximum results. Of the total 66 students, only 24 students or $36.36 \%$ were able to reach the completeness limit.

This initial step was taken to determine the type of media to be developed. After determining the type of media that will be developed, then a literature study is carried out by looking for references and literature related to Concrete Structure courses. Literature studies are also conducted to study concepts and theories regarding the product to be developed.

\subsection{Development Phase}

Preparation of Media Design

3.2.1 Drafting material

The initial step is to collect material from various relevant references. Compilation refers to the Semester Learning Plan.

\subsubsection{Preparation of material texts}

The preparation of material texts was used to explain the contents of the material in interactive multimedia. Material manuscripts are obtained from several Reinforced Concrete books, especially Ali Asroni's book, which is used in the Concrete Structure course.

3.2.3 Media creation tools

The most important software used is Adobe Flash Professional CS6.

\subsubsection{Storyboard development}

Storyboard is made to show a rough picture of multimedia learning that will be developed. The content that will be included in the learning media includes:

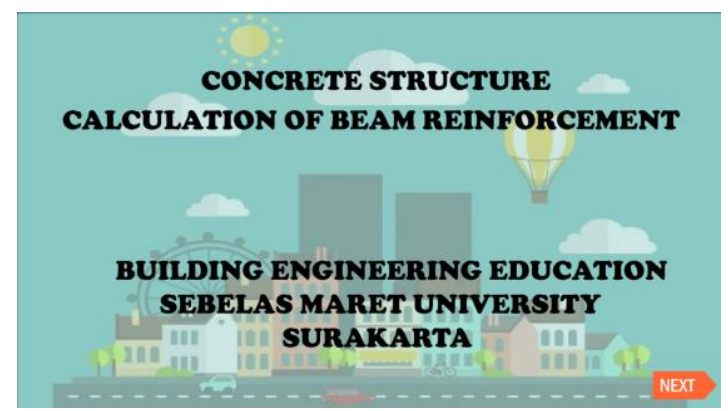

Fig. 1. Learning Multimedia Intro 


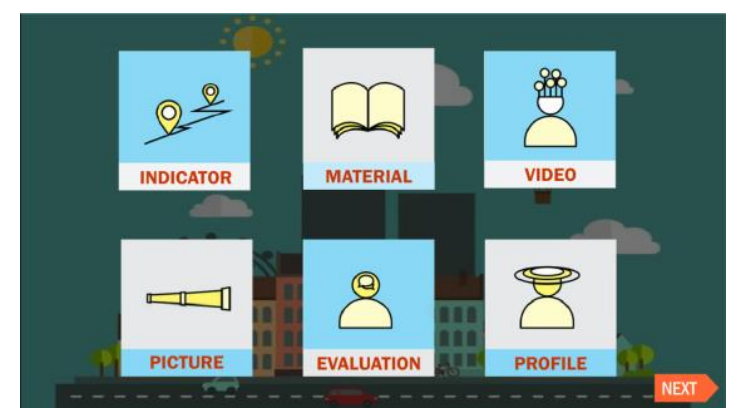

Fig. 2. Menu Page

\subsection{Production Stage}

The production step is carried out after the material to be collected is collected. In addition to material in the form of material, there are images used as background that support and reinforcement images made in 3 dimensions through SketchUp software.

\subsection{Preparation of Questionnaire Validation}

The validation questionnaire is prepared based on the indicators that have been planned according to the competence of each validator. So the questionnaire sheet is for different material, media and student experts.

\subsection{Validation of Expert Team (expert judgment)}

Validation by material experts who assess is a Civil Engineering lecturer, Faculty of Engineering, Sebelas Maret University, who is competent in the field of Structures. The following is the presentation of expert material assessment data in the form of diagrams can be seen in figure 3. as follows:

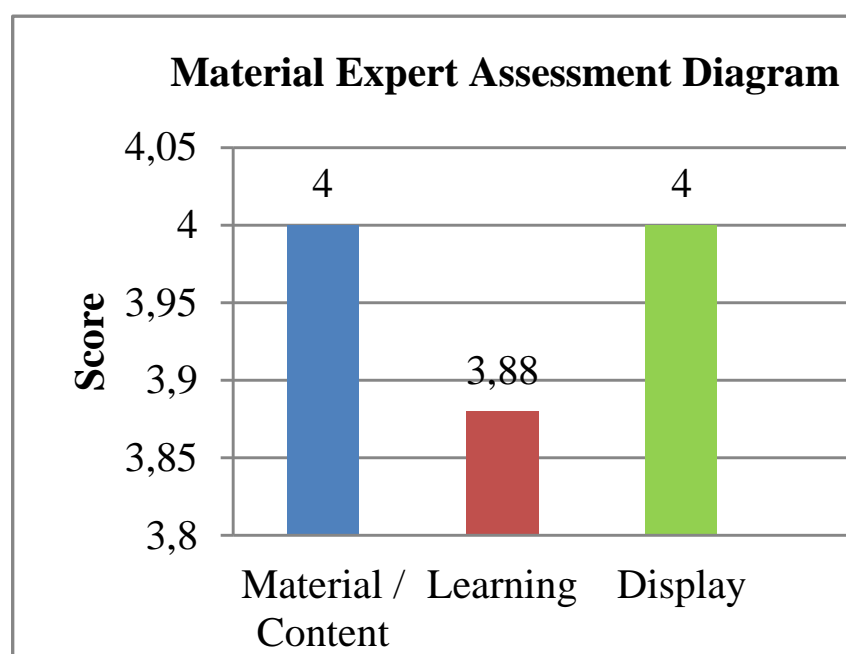

Fig. 3. Material Expert Assessment Diagram 
In accordance with the diagram on the assessment category, the total score of the assessment of the above material experts is included in the good category (Table I).

Validation by media experts who assessed were lecturers of Information and Computer Engineering Education, Faculty of Teacher Training and Education, Sebelas Maret University, who were competent in the field of technology. The following is the presentation of expert material assessment data in the form of a diagram can be seen in Figure 4. as follows:

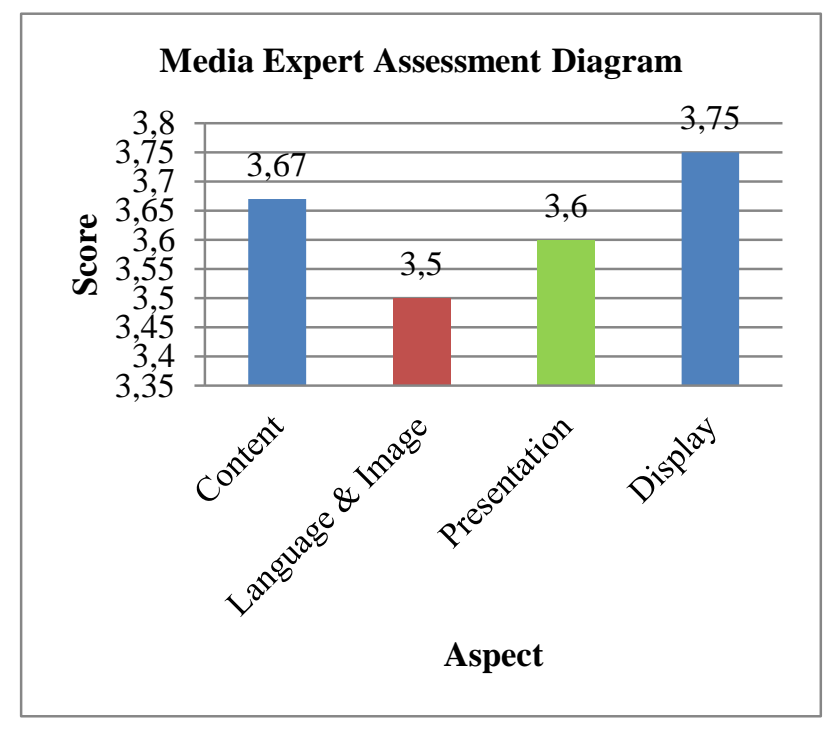

Fig. 4. Media Expert Assessment Diagram

In accordance with the diagram regarding the assessment category, the total value of the assessment of the media experts above is included in the good category.

\subsection{Evaluation and Revision of the Expert Team}

In general, material experts and media experts stated that the multimedia learning developed was good, but still needed to be improved for better results. Validation of the first media product is carried out to material experts and provides information that:

- Additional retained moment count controls.

- More attention is paid in writing, including writing MPa units (letter P capital).

- The color combination scheme counts, the basic colors of white and pink are less harmonious, replaced with a rather soft background.

- Need to navigate the music button settings (audio).

- Even better if interactive animation (quiz) is available.

The addition of quiz can be multiple choices or short entries. Here the researcher added interactive quiz using multiple choice. Because in other questions there are problems with the type of essay. In multiple choice quiz the user can choose one of the answers that he thinks is correct. When the answer is clicked, the correct answer will immediately appear along with the solution. 


\subsection{Field Trials}

Field trials of learning media Concrete Structures were carried out with respondents of 30 students of Building Engineering Education, Faculty of Teacher Training and Education, Sebelas Maret University, who took Concrete Structure courses. Field trials are carried out in the classroom by applying the media that has been designed. The researcher explained directly the material about square beams using media. Users in this field trial assessed the feasibility of the results of media design. The following is the presentation of the results of field trials in the form of a diagram in Figure 5.

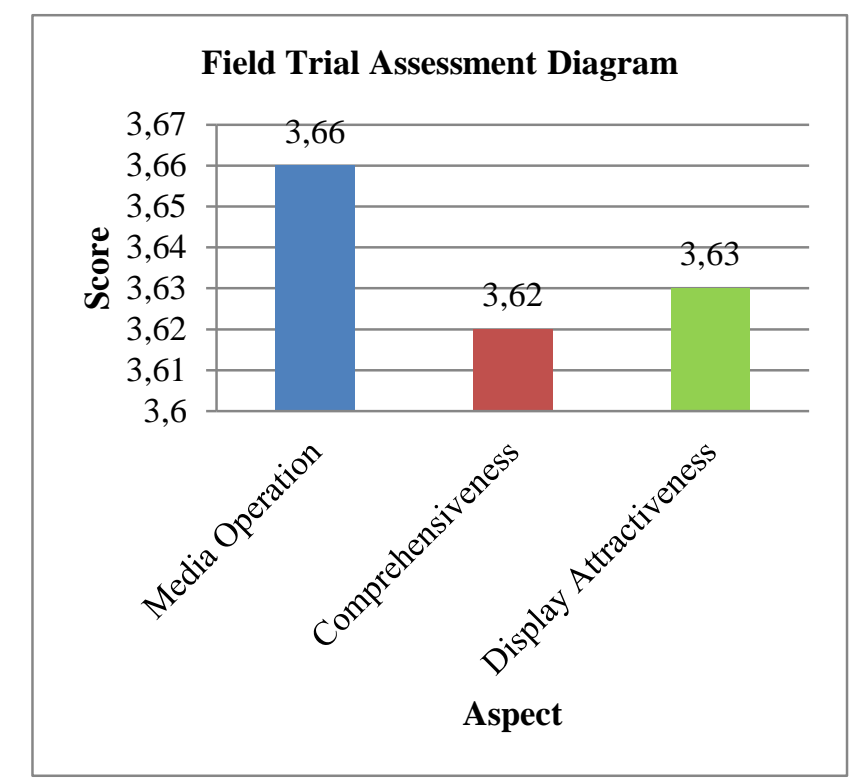

Fig 5. Field Trial Assessment Chart

In accordance with the diagram concerning the assessment category, the total score of the assessment of the material experts above is in the good category.

\subsection{Lecturer Lecture Interview Phase}

The researcher also conducted an interview to find out the opinion of the subject lecturers on the developed learning media. Because later the developed media is not only used for students, but as a medium to help lecturers in carrying out classroom learning. Although the assessment of experts and students get a good value and is suitable for use, but through interviews obtained input for improvement regarding the content of the material from the media. Some input from the lecturer briefly as below :

- Adding subtitle in video

- Adding multiple rebars video

- Adding images to the sample problem

- Addition of Basic Competencies on the Indicator page

- Addition of reinforcement philosophy as an introduction

- Adding stress-strain diagrams 
- For a single reinforcement image an example is made with reinforcement above and without reinforcement above.

\subsection{Final Product Improvement Phase}

The final model is an improvement part as well as an evaluation stage from the results of field trials and interviews of lecturers. Evaluation and revision of field trials were carried out based on the results of assessment of student response instruments on the application of learning media for Concrete Structure courses. In the field testing phase, it has been included in good criteria and decent category with an average of 3.64 so that there is no need to revise.

The evaluation and revision of the lecturer interview is based on the results of the interview and the lecturer's response to the Concrete Structure learning media. The lecturers give a lot of input on learning media. The input and opinions of the lecturers are more directed towards product improvement and to add material that is felt to be added.

After the learning media has passed through various validation processes by experts, users (students) at the field trial stage, then consulted the subject lecturers, the media is improved according to suggestions.

The final results of this study are interactive multimedia-based learning media that are ready to be used as learning media in Concrete Structure courses.

\section{Discussion}

\subsection{Preliminary Study}

In the 4.0 era brought many changes in human life. Industrial Revolution 4.0 is generally known as a change in the way of work that focuses on data management and technological progress. The success of a country in facing the 4.0 industrial revolution is closely related to innovation created by quality resources, so that Vocational Education is obliged to be able to answer challenges to face technological and competitive advances in this era. In creating quality and innovative resources for the technology, it is necessary to adjust learning facilities and infrastructure.

Concrete Structure is a compulsory subject in the Building Engineering Education study program. During this learning process that takes place in the Concrete Structure course, students use learning media in the form of modules and are still dependent on the lecturer when learning, so that students make many mistakes when doing calculations, not only that, but more attention is the lack of understanding of students, which is proven at the time of response, students do not understand what is written on their own work.

Various efforts have been made by the lecturer so that students are able to understand the material they convey. Although in reality there are currently no satisfactory results, where students have not all understood the material. One of the effort is to give assignments.

In addition to these efforts, other efforts carried out by the lecturer are by implementing a system of 4 competency tests, this is done so that students can learn little by little and the material can be absorbed better in such a way. 


\subsection{Teaching Media Development}

One of the goals of developing learning media is to make the quality of learning better. In the 4.0 era, there was a need for learning innovations to meet demands and respond to changes in the 4.0 era. In learning Concrete Structures, lecturers still use power point text media and no students have developed learning media in the Concrete Structure course. Because of this, researchers try to develop learning media.

In addition to these reasons, in this digital era, all information can be obtained easily through smartphones and internet technology which is growing very rapidly. So, technology must be developed and utilized optimally. Because inevitably, the digital era will be faced and affect the current generation that will have more impact on the internet and technology than reading books. Whereas with more and more complete information books about learning materials. Therefore, with the development of this media from material in books that are converted into media forms, students are expected to be easy to learn and not feel boredom.

Interactivity in multimedia assisted learning applications can and should go further than simply allowing a learner to choose their own path through an application by pointing and clicking at various menus items and buttons. If deep learning is to be promoted then the application should actively engage the user in carrying out tasks, which allow them to apply the new knowledge being presented. Reflection on that experience needs also to be encouraged. Multimedia affords many opportunities to do this [10]. This interactive multimedia is presented concisely and added supporting learning images and videos. In addition, media that is developed attractively, creatively, communicatively and innovatively will motivate students to learn.

Development of learning media Concrete Structure courses refers to the category of interactive multimedia, namely learning media equipped with a controller (button) that can be controlled by the user. Users in this case students can choose the desired Concrete Structure material. Students and lecturers can open the multimedia on a cellphone if the cellphone is equipped with a Flash Game Player application on an android-based cellphone. Flash Game Player can be downloaded on the Play Store and only requires space on a cellphone of 43 Mega Bytes.

Regarding the internet of thing (IoT), the multimedia can be accessed easily by students if the lecturer can upload the file to the Sebelas Maret University Open Course Ware (OCW) page. Sebelas Maret University OCW is a publication of web-based learning resources that are free to be used by lecturers and students around the world. Sebelas Maret University OCW serves to help students who are looking for additional course material, as well as some supporting information about an existing course.

\subsection{Results of Evaluation of Learning Media}

After going through various stages of development, a multimedia learning can be produced that can be displayed in class or to study anywhere using a computer or mobile device. This media describes the material in sequence from the theory of calculating square beam reinforcement. In this media there are also examples of questions in the form of essay and multiple choice questions and practice questions. 
4.3.1 Media evaluation by validator / expert

Development of interactive multimedia-based learning media followed by learning media assessment. The quality test or the feasibility of the learning media is done by validating the assessment by material experts and media experts.

Assessment of learning media by material experts was obtained: the content / material aspect was 4.00; learning aspects of 3.88; and the display aspect is 4.00.

Assessment of learning media by media experts obtained aspects of content / material of 3.67; aspects of language and images are 3.50; Presentation aspect is 3.60; and programming aspects of 3.75 .

4.3.2 Process of assessment by students

The assessment process by experts has been carried out, then revisions are made. After being revised, then field trials were conducted by taking 30 students of Building Engineering Education Faculty of Teacher Training and Education, Sebelas Maret University who had taken the Concrete Structure course. In this field trial obtained an average score of 3.64 with the following details; aspects of media operation obtained a score of 3.66; comprehensiveness of 3.62; and display attractiveness of 3.63.

Feasibility of learning media Concrete Structures reviewed by material experts, media experts, and students as users / users of learning media through assessment validation in the form of instruments, can be seen in table 2 below:

Table 2. Feasibility Based On Assessment Instrument

\begin{tabular}{lll}
\hline Evaluation & Interval & Category \\
\hline Material expert (1 lecturer) & 3.96 & Good \\
Media experts (1 lecturer) & 3.63 & Good \\
Students (Field trial) & 3.64 & Good \\
\hline
\end{tabular}

\subsubsection{Interview with subject lecturers}

In addition to assessment by experts and students as users, instructional media were also consulted with subject lecturers. Interviews were conducted to find out the problems in the field besides that to get input on the developed media. Whether the material in the media is correct or there are still things that need to be added. From the interview process, there were many inputs from the lecturers. After getting input, the learning media was revised.

From the interview process, researchers can conclude that lecturers and students benefit from the development of interactive multimedia. Lecturers argue that the media is very helpful for the learning process and is worthy of use. Lecturers feel happy that students have taken the initiative to make materials like this in the form of media. For complete development it may not yet be, it will be the duty of the lecturer to add important points that must be added, but for explanation, the notion of reinforced concrete is more than enough and very helpful for lecturers and students.

\section{Reference}

[1] Ashjan, M.: What is next with makerspace professional investigationof friendly features for a virtual makerspace ?. Proceedings of The IIER International Conference, UEA. pp. 1-4. (2017)

[2] Chomyim, C., Chaisanit, S., \& Trangansri, A.: E-textbookas new resource for robotic course. 
Proceedings of $20^{\text {th }}$ ISERD International Conference, Hong Kong. pp. 3-6. (2015)

[3] Gall, M. D., Borg, W. R., \& Lietke, G. E.: Educational research: a guide for preparing a thesis or dissertation proposal in education. New York. Retrieved from http://books.google.com.au/books?id=GX01AQAAIAAJ (1989)

[4] Jani, J.: Malaysian traditional games as innovation in teaching netball , modified from teaching games for understanding method inphysical education. Proceedings of ISER 17th International Conference, Auckland, New Zealand. pp. 24-28. (2016)

[5] Nesbit, J. C., Leacock, T. L., Xin, C., City, C., Highway, K. G., \& Richards, G.: Learning object evaluation and convergent participation : tools for professional development in e-learning interactive arts and technology interactive arts and technology e-learning innovation centre british columbia institute of technology. (2004)

[6] Majumdar, M. K., Choudhury, S., Kumar, R., \& Sen, A.: Standard time calculation (STC) for elearning. Proceedings of Nineteenth TheIIER International Conference, Thailand. pp. 116-118. (2015)

[7] Sabates, R., Salter, E., Bromberg, T., Voss-Dahm, D., Obolenskaya, P., \& Bosch, G.: Social benefits of vocational education and training for individuals: concepts, contexts and empirical results. pp. 0-70. Retrieved from http://www.iaq.uni-due.de/aktuell/veroeff/2010/bromberg_1.pdf (2010)

[8] Schroeder, W.: Germany's Industry 4.0 strategy Rhine capitalism in the age of digitalisation. Friedrich Ebert Stiftung, England. pp. 0-16. (2016)

[9] Seitz, H., Metzger, C., \& Kobler, C.: Vocational education in switzerland - characteristics, challenges and strategies. Berufs-und Wirtschaftspädagogik, Germany. Vol (7). pp. 1-25. (2005)

[10] S. Cairncross: Interactive multimedia and learning: realizing the benefits. Innovations in Education and Teaching International, UK. pp. 156-164. (2001)

[11] T. Mccrone and C. O. Beirne: Report a review of technical education a review of technical education. National Foundation for Educational Research. pp. 1-33. (2015)

[12] Wang, T. J.. Educational benefits of multimedia skills training. TechTrends. Vol 54 (1). pp. 47 57. (2010)

[13] Windiahsari: Task based learning in teaching english. Proceedings of Academics World $31^{\text {st }}$ International Conference, Singapore. pp. 2-6. (2016)

[14] Zairoslawanee Zaib; Hairuddin Harun: Leadership in technical and vocational education: towards excellence human capital. J. Educ. Pract. Vol. 5 (23). pp. 132-136. (2014)

[15] Zardasht mohammed raouf hussein, \& saleh, n. b.: The effect of learning programming in the achievement of the snatch levels lifting at the school of physical education students at the university of Sulaymaniyah. Proceedings of ISER 40 ${ }^{\text {th }}$ International Conference, Germany. (2016) 